\title{
Cutaneous Crohn's disease of the vulva
}

\author{
Daisy Duan, ${ }^{1}$ Mary L Stevenson, ${ }^{2}$ Lisa B Malter, ${ }^{3}$ Miriam Keltz Pomeranz ${ }^{2}$
}

${ }^{1}$ New York University School of Medicine, New York, New York, USA

${ }^{2}$ The Ronald 0 Perelman Department of Dermatology, New York University Langone Medical Center, New York, New York, USA

${ }^{3}$ Department of Medicine, New York University School of Medicine/Bellevue Hospital Center, New York, New York, USA

\section{Correspondence to} Dr Mary L Stevenson, mary.stevenson@nyumc.org

Accepted 15 March 2014

\section{DESCRIPTION}

A 26-year-old woman was referred to dermatology department from an outside clinic for a 1-year history of recurrent draining lesions of the vulva and buttock treated unsuccessfully with doxycycline for presumed lymphogranuloma venereum. Physical examination was notable for an oedematous vulva (figure 1) with knife-like fissuring of the genitocrural folds (figure 2), superficial erosions and scattered draining papulonodules (figure 1). Biopsy showed granulomatous dermatitis consistent with cutaneous Crohn's disease. Colonoscopy revealed normal-appearing mucosa in the colon and terminal ileum, however, random biopsies demonstrated patchy, chronic inactive colitis with microgranulomas. MRI of the pelvis revealed multiple perivaginal and perirectal fistulas. The patient was initially managed with oral metronidazole and intralesional corticosteroid injections of the groin. She was started on adalimumab $40 \mathrm{mg}$. Her clinical course was complicated by recurrent perianal and axillary abscesses, requiring antibiotics, incision and drainage, and deferral of adalimumab, which was reinitiated following resolution of her active infections.

Cutaneous Crohn's manifesting with vulvar lesions is an under-recognised condition, with only 101 cases having been reported since $1965 .^{1}$ The most frequently observed lesions include vulvar oedema (figure 1), 'knife-like' ulcerations (figure 2),

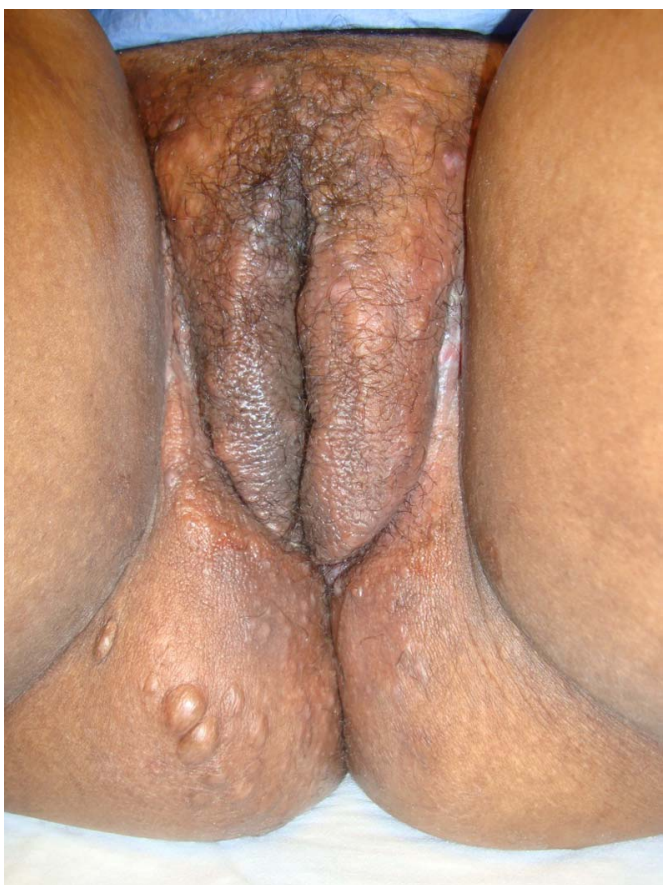

Figure 1 Oedematous vulva with superficial erosions and scattered papulonodules.

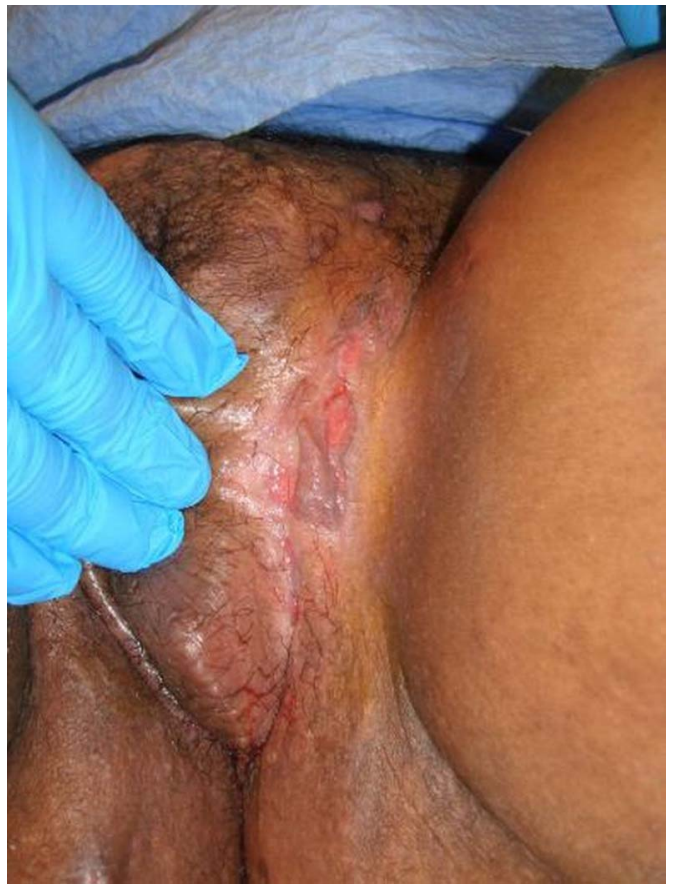

Figure 2 Knife-like fissuring of the genitocrural folds.

hypertrophic lesions and chronic suppuration. Cutaneous Crohn's should be included on the differential diagnosis of vulvar lesions as these lesions may precede the diagnosis of gastrointestinal disease in $25 \%$ of cases. ${ }^{2}$ The differential diagnosis includes infections, lymphogranuloma venereum, granuloma inguinale, hidradenitis suppurativa and syphilis. Common treatments include oral steroids, metronidazole, azathioprine and 5-aminosalicylates. In addition, several case reports have documented successfully treated cutaneous Crohn's disease with either infliximab or adalimumab in patients who have failed other systemic immunosuppressive therapy. $^{3}$

\section{Learning points}

Cutaneous Crohn's disease may present in patients without gastrointestinal symptoms.

- Vulvar lesions of cutaneous Crohn's are classically linear 'knife-like' ulcerations along the genitocrural folds and vulvar oedema.

- Treatment of cutaneous Crohn's disease requires a multidisciplinary approach, and while no specific treatment guidelines exist antitumour necrosis factor therapy may be a promising treatment option for control of this disease. 
Contributors All the authors were involved with the clinical care of the patient. DD conducted literature search and initial drafting of the manuscript. MLS developed the idea for the article and was involved with the drafting of the manuscript. LBM and MKP performed the final editing of the manuscript. MKP provided the photographs.

Competing interests None.

Patient consent Obtained.

Provenance and peer review Not commissioned; externally peer reviewed.

\section{REFERENCES}

1 Barret M, de Parades V, Battistella M, et al. Crohn's disease of the vulva. J Crohns Colitis Published Online First: 16 Nov 2013. doi:10.1016/j.crohns.2013.10.009

2 Andreani S, Ratnasingham K, Dang H, et al. Crohn's disease of the vulva. Int I Surg 2010;8:2-5.

3 Yoong C, Schofield C, Rodins K, et al. Cutaneous Crohn's disease treated with infliximab and 4 years of follow up. Australas J Dermatol Published Online First: 18 Jun 2013. doi:10.1111/ajd.12069

Copyright 2014 BMJ Publishing Group. All rights reserved. For permission to reuse any of this content visit http://group.bmj.com/group/rights-licensing/permissions.

BMJ Case Report Fellows may re-use this article for personal use and teaching without any further permission.

Become a Fellow of BMJ Case Reports today and you can:

- Submit as many cases as you like

- Enjoy fast sympathetic peer review and rapid publication of accepted articles

- Access all the published articles

- Re-use any of the published material for personal use and teaching without further permission

For information on Institutional Fellowships contact consortiasales@bmjgroup.com

Visit casereports.bmj.com for more articles like this and to become a Fellow 